\title{
Impact of growing conditions on the gum properties of different genotypes of guar (Cyamopsis tetragonoloba (L.) Taub.)
} \author{
A.V. Balashov ${ }^{3}$, E.V. Rusinova ${ }^{3}$, P.G. Rusinov ${ }^{3}$, E.K. Potokina ${ }^{2}$ @ \\ ${ }^{1}$ AMT, Ltd., St. Petersburg, Russia \\ ${ }^{2}$ Federal Research Center the N.I. Vavilov All-Russian Institute of Plant Genetic Resources (VIR), St. Petersburg, Russia \\ ${ }^{3}$ NIKA PetroTech, Ekaterinburg, Russia \\ @e-mail: e.potokina@vir.nw.ru
}

I.V. Kruchina-Bogdanov ${ }^{1}$, E.V. Miroshnichenko ${ }^{2}$, R.A. Shaukharov ${ }^{2}$, E.N. Kantemirova², M.A. Golovina², K.M. Abdullaev²,

Galactomannan (gum), a water-soluble polysaccharide, is widely used as a gelling agent in liquids, including in the oil and gas industry for hydraulic fracturing. The most effective source of this valuable plant material is seeds of guar (Cyamopsis tetragonoloba (L.) Taub.), a legume crop new for Russia. Although in recent years progress has been made in the selection of guar varieties adapted to the conditions of the Russian Federation, the question of the most appropriate region for the cultivation of this crop remains open. The purpose of the study was to investigate how a region and technology of guar cultivation can affect the main indicators of the final target product: the content and viscosity of guar gum extracted from the seeds of various guar genotypes. To understand this, ecogeographical tests of 13 guar accessions from the VIR collection were conducted at the experimental stations of the Vavilov Institute (VIR), where climatic conditions correspond to the temperature requirements of the crop. To compare the properties of gum extracted from the seeds of various genotypes, a fast-tracked laboratory method was suggested allowing gum extracts to be obtained for assessing their viscosity. The method allows fast screening of the breeding material and selecting guar genotypes with beneficial properties of guar gum which are in demand by the oil industry. Applying the fast laboratory method for assessing the properties of gum in seeds of 13 guar varieties showed that the content and viscosity of gum of the same variety vary greatly depending on growing conditions. The same set of 13 guar accessions was grown in 2018 at the Volgograd, Astrakhan, Dagestan and Kuban VIR experimental stations. As a result, the maximum viscosity values were obtained for the seeds reproduced at the Astrakhan region, where the guar was grown on irrigated lands. On the other hand, the maximum gum content in the seeds of all accessions was recorded when they were grown in the Volgograd region. The results showed that the guar gum extracted from seeds of guar plants grown in the Russian Federation can be used as a gelling agent in the processes of intensification of oil production by the method of hydraulic fracturing. This experience is new to the Russian Federation. Key words: Cyamopsis tetragonoloba (L.) Taub.; guar; method for assessing guar gum content and viscosity; guar varieties; ecological testing; regions of propagation.

For citation: Kruchina-Bogdanov I.V., Miroshnichenko E.V., Shaukharov R.A., Kantemirova E.N., Golovina M.A., Abdullaev K.M., Balashov A.V., Rusinova E.V., Rusinov P.G., Potokina E.K. Impact of growing conditions on the gum properties of different genotypes of guar (Cyamopsis tetragonoloba (L.) Taub.). Vavilovskii Zhurnal Genetiki i Selektsii = Vavilov Journal of Genetics and Breeding. 2019;23(7):941-948. DOI 10.18699/VJ19.570

\section{Влияние условий выращивания различных генотипов гуара (Cyamopsis tetragonoloba (L.) Taub.) на свойства камеди семян}

И.В. Кручина-Богданов ${ }^{1}$, Е.В. Мирошниченко ${ }^{2}$, Р.А. Шаухаров ${ }^{2}$, Е.Н. Кантемирова ${ }^{2}$, М.А. Головина ${ }^{2}$, К.М. АбАумлаев ${ }^{2}$, А.В. Бамашов ${ }^{3}$, Е.В. Русинова ${ }^{3}$, П.Г. Русинов ${ }^{3}$, Е.К. Потокина ${ }^{2} \otimes$

\footnotetext{
1 ОоО «АМТ», Санкт-Петербург, Россия

${ }^{2}$ Федеральный исследовательский центр Всероссийский институт генетических ресурсов растений им. Н.И. Вавилова (ВИР), Санкт-Петербург, Россия 3 ООО «НИКА Петротэк», Екатеринбург, Россия

@e-mail: e.potokina@vir.nw.ru
}

\begin{abstract}
Галактоманнан (камедь) - растворимый в воде полисахарид, используется в качестве гелеобразующего агента в жидкостях, в том числе в нефте- и газодобывающей промышленности для гидравлического разрыва пласта. Самым эффективным источником этого ценного растительного сырья (гуаровой камеди) являются семена гуара (Cyamopsis tetragonoloba (L.) Taub.), новой для Российской Федерации сельскохозяйственной культуры. Хотя за последние годы были достигнуты определенные успехи в селекции сортов гуара, адаптированных к условиям РФ, вопрос о наиболее подходящем регионе возделывания этой культуры остается открытым. Цель проведенных исследований заключалась в том, чтобы установить, в какой степени регион и технология выращивания гуара могут влиять на основные показатели конечного целевого продукта - содержание и вязкость камеди в семенах различных генотипов гуара. Для решения этого вопроса в 2017-2018 гг. были проведены эколого-географические испытания образцов гуара коллекции ВИР на опытных станциях института, климатические условия которых отвечают критериям теплообеспеченности этой культуры. Для сравнительного изучения свойств камеди в семенах различных генотипов гуара
\end{abstract}




\begin{abstract}
впервые предложен ускоренный лабораторный метод получения вытяжек камеди для вискозиметрической оценки. Разработанный метод позволяет проводить ускоренный скрининг исходного материала для селекции сортов гуара, перспективных с точки зрения использования камеди из их семян в нефтедобывающей промышленности. В результате лабораторной оценки содержания и вязкости камеди, содержащейся в семенах 13 образцов гуара, обнаружено, что выход и свойства камеди одного и того же сорта сильно варьируют в зависимости от условий произрастания. Эксперимент 2018 г. по выращиванию одного и того же набора 13 образцов на Волгоградской, Астраханской, Дагестанской и Кубанской опытных станциях ВИР показал, что максимальные показатели удельной вязкости получены для семян репродукции Астраханской ОС ВИР, где гуар выращивался на поливе. С другой стороны, максимальное процентное содержание камеди в семенах у всех образцов гуара было зафиксировано при их выращивании в условиях Волгоградской ОС ВИР на капельном орошении. Результаты дополнительного тестирования образцов порошковой формы гуаровой камеди, полученной из семян сортов отечественной селекции, позволяют сделать вывод о пригодности продукта для использования в качестве гелеобразователя в процессах интенсификации добычи нефти методом гидравлического разрыва пласта. Данный опыт является уникальным для России.

Ключевые слова: гуар; камедь; содержание и вязкость; методика оценки; сорта; экологические испытания; регионы выращивания.
\end{abstract}

\section{Introduction}

Seeds of guar (Cyamopsis tetragonoloba (L.) Taub.), the new agriculture legume crop of the Russian Federation, serve as a source of a valuable vegetable product - guar gum. The latter mainly consists of the polysaccharides galactomannans which are able to increase the viscosity of the solution, even at low concentrations. Galactomannans, along with cellulose, starch, xyloglucan, xanthan gum and dextran, are the most economically demanded polysaccharides. Galactomannan is found in the seed endosperm of many plants. While several species are considered as a possible source of this substance, mainly three legume species - Cyamopsis tetragonoloba (L.) Taub., Ceratonia siliqua L. and Caesalpinia spinosa (Molina) Kuntze are used for the industrial production of plant gum (Thombare et al., 2016). With that, guar gum is extracted by the easiest and cheapest way, stimulating increased interest in guar, as an agricultural crop (McArdle et al., 2011).

Guar belongs to a rare group of legume species whose seeds contain a developed endosperm instead of large cotyledons, which are common for most legumes (Hanson, 2015). In the cell walls of the guar endosperm, as well as within the cells of this storage tissue, galactomannan inclusions are concentrated to provide energy to the developing plant during germination. All components of the guar seed are used in industry, and the raw materials obtained from them have a specific name: the hull (churi) covers two endosperm halves (splits) in the cells of which galactomannan is stored. The endosperm in turn surrounds two cotyledons including the embryo (korma).

The technology for producing powdered gum from guar seeds is the know-how of many commercial companies. The general scheme of the process usually includes several main stages: seeds are divided into two halves (split) which are dried at high temperature. As a result, the cotyledons with the embryo are easily separated from the endosperm. The separated endosperm halves are heated, the seed hull is softened, and then separated from the endosperm using various devices, such as mechanical grinders, attrition and roller mills. As soon as the endosperm is separated from other tissues of the seed, it is ground into a powder, from which galactomannan is extracted by the precipitation with ethanol, then dried. The final product is a homogeneous white powder, similar in texture to wheat flour. The most important criteria of the quality of the product are mesh size and viscosity of the aqueous solution, which is measured under standard conditions, often using a Brookfield viscometer (Abidi et al., 2015). The amount and molecular weight of the galactomannan found in the endosperm extract can vary significantly, depending on the source of the seed and the growing conditions (Ellis et al., 2001). Thus, for the successful introduction guar in the Russian Federation, the correct choice of regions and environmental conditions for the cultivation of this crop is just as important as breeding of new varieties.

In all areas of the Russian Federation, the main limiting factor for guar cultivation is the sum of effective temperatures during the growing season. From the analysis of temperature and humidity parameters of the agro-climatic zones of the Russian Federation it follows that a number of regions of the Crimea, Dagestan, Krasnodar, Stavropol and Rostov as well as the southern Volga, are suitable for guar cultivation since in those regions the sum of effective temperatures above $10^{\circ} \mathrm{C}$ exceeds $3400-3500{ }^{\circ} \mathrm{C}$ (Lebed et al., 2017).

Although guar breeding in Russia started just recently, by 2018 the State Register of Breeding Achievements had registered five new guar varieties allowed for cultivation in the Russian Federation. Nevertheless, the question of the most suitable region for the crop cultivation still remains open, in particular, due to the lack of information on the quality of guar gum obtained from seeds that were produced in different ecogeographical regions. To solve this problem, in 2017-2018 the Vavilov All-Russian Institute of Plant Genetic resources (VIR) carried out ecological testing of its guar germplasm collection at the VIR experimental stations where climatic conditions corresponded to the temperature requirements of the crop. The purpose of the tests was primarily to establish to what extent the region and a growing technology can affect the main quality indicators of the final target product - the content and viscosity of the gum extracted from the seeds of different guar genotypes.

To date, there is no generally accepted standard or any arbitration method for assessing the capability of seeds of various guar genotypes to serve as a good raw material the production of gum of a certain viscosity. In the published reports two independent processes are usually described: 1) the isolation and purification of gum from seeds to estimate the gum yield, 
and 2) the preparation of a solution from the obtained guar gum followed by a measurement of its viscosity (Cerqueira et al., 2009; Eldirany et al., 2015). These techniques are usually executed by different performers and are separated in time. Here, for the first time, we propose a method for assessing the quality of guar seeds for the both indicators - gum yield and viscosity - in one step, which opens up the possibility for extensive screening of various guar genotypes using compact and affordable means.

\section{Material and methods}

13 accessions promising in their agrobiological characteristics according to the results of their preliminary evaluation in 2017 at the Kuban branch of the VIR (Krasnodar region) were included in the ecological tests (Table 1). In 2018, the same set of seed accessions of a single reproduction of the Kuban branch was distributed across all geographical locations where ecological trials were planned. The amount of seeds in each location was enough to conduct field trials on an area of $10 \mathrm{~m}^{2}$ for each accession.

Determination of the content and viscosity of gum extracted from guar seeds. Mass screening was carried out according to the newly developed method of laboratory assessment of the content and viscosity of gum in guar seeds. The average seed sample taken in an amount of $2.0 \mathrm{~g}$ (exact weight) was placed in a wide laboratory beaker with a capacity of $150 \mathrm{~cm}^{3}$. Seeds in the beaker were poured into $15 \mathrm{~cm}^{3}$ of distilled water and placed in an autoclave. Boiling of the soaked seeds was carried out by holding for $30 \mathrm{~min}$ at a temperature of $121^{\circ} \mathrm{C}$.

Then, after removing the water, the boiled seeds were placed in a beaker with $50 \mathrm{~cm}^{3}$ of distilled water and stirred on a magnetic stirrer for 2 hours at room temperature. The obtained extract was separated by centrifugation at $7000 \mathrm{~min}^{-1}$ for $15 \mathrm{~min}$. The separated precipitate was re-extracted into $50 \mathrm{~cm}^{3}$ of distilled water on a magnetic stirrer for 1 hour at room temperature. The centrifugation and extraction procedure was repeated one more time, and clarified solutions after centrifugation were combined to obtain a final extract volume of $140-160 \mathrm{~cm}^{3}$. Using the measuring cylinder, the resulting final volume of the gum extract was estimated with an accuracy of $\pm 1 \mathrm{ml}$.

The dynamic viscosity of the resulting clarified solution was measured at room temperature on a Brookfield rotational viscometer (spindle L2, rotation speed $100 \mathrm{~min}^{-1}$ ). The viscosity was recorded for $40 \mathrm{~min}$, scoring the initial and final value. In the solution after measuring the viscosity, the concentration of "raw gum" was determined as the solids content according to standards (GOST 33977-2016, http://protect.gost.ru/).

The final viscosity estimation result was taken at the end of the measurement. The estimated relative viscosity values were calculated from the measured values of viscosity and gum concentration as follows:

$$
\eta_{\mathrm{er}}=\frac{\eta-\eta_{0}}{\eta_{0} c}
$$

where: $\eta$ - the measured value of the gum solution viscosity, $\mathrm{mPa} \cdot \mathrm{s} ; \eta_{0}-$ viscosity of solvent (for water $\eta_{0}=1 \mathrm{mPa} \cdot \mathrm{s}$ ); $c$ - "raw gum" concentration in the extract, \%.
Table 1. List of guar accessions from the VIR collection involved in ecological trials in 2018

\begin{tabular}{|c|c|c|c|}
\hline No. & $\begin{array}{l}\text { No. in } \\
\text { VIR } \\
\text { Catalogue }\end{array}$ & $\begin{array}{l}\text { Where from } \\
\text { the seed material } \\
\text { was obtained }\end{array}$ & Variety \\
\hline 1 & 52568 & Argentina & Unknown \\
\hline 2 & 52569 & Pakistan & Unknown \\
\hline 3 & 52571 & Crimea & Unknown \\
\hline 4 & 52572 & \multirow[t]{4}{*}{ Krasnodar region } & Vavilovskii 130 \\
\hline 5 & 52573 & & Kubanskii \\
\hline 6 & 52574 & & Vector \\
\hline 7 & 52575 & & Sinus \\
\hline 8 & 52580 & \multirow[t]{2}{*}{ Rostov region } & Unknown \\
\hline 9 & 52581 & & Unknown \\
\hline 10 & 52584 & \multirow[t]{3}{*}{ USA } & Santa Cruz \\
\hline 11 & 52585 & & Kinman \\
\hline 12 & 52586 & & Lewis \\
\hline 13 & 52742 & Krasnodar region & Kubanskii Jubileinyi \\
\hline
\end{tabular}

The gum content (GC) in the seeds (in \%) was calculated as the ratio of the amount of extracted gum in the solution to the initial seed weight:

$$
\mathrm{GC}=\frac{c \cdot \rho \cdot V}{a}
$$

where: $\rho-$ the density of the gum extract (at a concentration of gum less than $0.6 \%$ should be taken $\rho=1 \mathrm{~g} / \mathrm{cm}^{3}$ ); $V$ - measured final volume of gum extract, $\mathrm{cm}^{3} ; a-$ seed sample taken for extraction, g.

The properties of dry powder guar gum samples, including stability and operating parameters as a gelling agent for hydraulic fracturing fluid, were analyzed in the laboratory of NIKA PetroTech company. A common oil industry method for measuring the viscosity of a $0.48 \%$ guar solution was used. This solution would be commonly called a "40 lb gel” since contains $40 \mathrm{lb}$ of guar mixed into 1000 gal of water and at $511 \mathrm{~s}^{-1}$ gives a viscosity of 30-45 centipoise (cP), depending on the quality of the guar gum (Abidi et al., 2015).

Statistical data analysis was carried out using the Statistica 12

\section{Results}

\section{Ecological trials of guar accessions} at VIR experimental stations

Growing experiments with the set of 13 guar accessions (see Table 1) were carried out in 2018 at four branches of VIR: Kuban (Gulkevichsky District, Krasnodar region), Astrakhan (Astrakhan), Volgograd (Volgograd), Dagestan (Derbent, Daghestan). Peculiarities of agro-climatic conditions in four geographical points where the tests were carried out are given below.

Kuban branch. Seeds were sown in the last decade of May. Irrigation was not applied. During germination period 
and further from May 28th to July 26th, abnormally high air temperatures ranging from 30 to $37.6{ }^{\circ} \mathrm{C}$ were recorded, with no any precipitation and strong dry winds, which led to the drying out of the soil horizon to a depth of 20-25 cm. The soil temperature at a depth of $20 \mathrm{~cm}$ in the first ten days of June was $21.8^{\circ} \mathrm{C}$, in the second $-23.8^{\circ} \mathrm{C}$, causing cracking of the soil arable horizon with wide crevices up to $2-5 \mathrm{~cm}$ to a depth of 50-60 cm. Such climatic indicators deviate from long-term averages, they occur with a frequency of once every 15-20 years and are stressful for the guar culture.

Daghestan branch. In the soil and climatic conditions of Dagestan (semi-dry subtropics) guar was grown for the first time. Irrigation (irrigation furrows) was used. Before the maturing phase, the plants developed quickly showing vigorous young growth. Then, however, heavy precipitation fell in mid-August, after which plants in the phase of the maturation of lower beans were affected by Alternaria pathogen. As the result, epiphytotic injury was recorded by September (4-5 points of defeat at 5- and point scale). This negatively affected all indicators of productivity.

Volgograd branch. The climate of the Lower Volga region, where the experimental station is located, is extremely continental. Spring is dry with a rapid increase in daytime temperatures and frequent strong winds. Summer is hot and dry with the scorching heat (air temperature is often above $40{ }^{\circ} \mathrm{C}$, no precipitation). Throughout the growing season of guar, a drip irrigation system was used. Guar seeds were sown in mid-May in a well-heated soil at a depth of $2-3 \mathrm{~cm}$, after the soil furrows were well moistened with water. Pronounced cooling in late May - early June negatively affected the development of guar, the plants turned yellow, some of them died. Nevertheless, after that, under fairly dry weather, high air temperature and drip irrigation, guar plants grew quite strong and branched (up to $123 \mathrm{~cm}$ in height). During the growing season of guar, Aphid and Alternaria lesions were monitored - only a small injury of individual plants was recorded.

Astrakhan branch. The branch is located in the southern part of the Astrakhan region in the delta of Volga river. The Astrakhan region is the most droughty area in Russia, generally characterized as extremely continental. Seeds were sown in the first decade of May. Sowing was carried out in irrigation furrows, the seeds were planted in moist soil manually. In order to preserve moisture and prevent the appearance of soil crust, manual row harrowing was carried out 5-6 days after sowing. Subsequently, the care of the crops consisted of timely manual weeding, cultivation and drip irrigation.

\section{The rapid laboratory assessment of the content and viscosity of gum in guar seeds}

For mass screening of breeding guar material for the content and quality of gum, we propose a rapid laboratory method for producing gum extracts from guar seeds with subsequent viscometric evaluation, without isolating the gum itself in its pure form. The developed method is based on the extraction of gum from boiled guar seeds. The boiling conditions $\left(121^{\circ} \mathrm{C}\right.$, $30 \mathrm{~min}$ ) were chosen experimentally to ensure sufficient swelling of the endosperm polysaccharides to perforate the seed coat, but at the same time to prevent loss of gum when the seeds are soaked in water. Thus, instead of many hours of seed soaking process followed by isolation and drying of the endosperm halves (Eldirany et al., 2015), the whole procedure takes 6 hours, including measuring the viscosity and calculating the solids content.

The viscosity of the obtained extract with a solids concentration of $0.35-0.55 \%$ is measured using a rotational viscometer. The measured value is adjusted to the solids concentration of the extract, obtaining the value of the specific viscosity. Other water-soluble components of guar seeds do not interfere with determination.

The generally accepted assessment of the viscosity of guar gum solutions involves the use of rotational viscosimetry at gum concentrations of about $0.5 \%$ (see ECFA FAO Monographs 5,2008$)$. The amount of seeds ( $2.0 \mathrm{~g}$ ) taken for analysis (considering the content of gum in the seeds from 30 to $50 \%$ and the final extract volume of $150-200 \mathrm{~cm}^{3}$ ) allows to ensure the concentration of gum in the aqueous extract at the level of the desired $0.5 \%$.

The availability of endosperm polysaccharides for extraction is determined by the completeness of their hydration. Previously, it was reported that hydration seed treatment requires a long-term soaking of about 16 hours (Eldirany et al., 2015). During the developing of our method, we experimentally established that the degree of hydration of the seeds (by their volume and residual hardness of the swollen phase), corresponding to 16 hours of soaking at room temperature, can be achieved in 2 hours of boiling at atmospheric pressure or in $30 \mathrm{~min}$ of boiling at $121^{\circ} \mathrm{C}$.

To prove this, we estimated the yield of gum polysaccharides in solution by changing the viscosity of the extract depending on the duration of extraction (Fig. 1).

The extraction conditions that were established experimentally (3 cycles of 4 hours) provide a gum output of at least $95 \%$ of those determined by the conventional method after endosperm halves isolation, and allow the entire analysis procedure to be completed in 6 hours, including boiling and measuring the viscosity. Gum in a solution purified by centrifugation makes up at least 90-95\% by weight of the solids content. That allows, with sufficient accuracy for the express method, to equate content of gum in the extract to the total solids content.

The proposed method allows to estimate the content of gum in guar seeds and its specific viscosity based on only two measurements - the viscosity of the extract and the dry matter content in it - with knowing the weight of the seed sample and the volume of the obtained extract. The specific viscosity index is dimensionless. For its calculation, the concentration of solids in the extract is taken into account, the dynamic viscosity of which is measured by a rotational viscometer in $\mathrm{cP}$ (or $\mathrm{mPa} \cdot \mathrm{s})$. This allows the use of a single scale for a comparative assessment of extracts from various unknown samples of guar seeds with different concentrations of gum.

To verify the effectiveness of the proposed method, we estimated the viscosity of the gum samples for two guar varieties - cv. Kubanskii and Kubanskii Jubileinyi using the traditional method, after isolation of the endosperm and preparation of dry guar gum powder. The results coincided with those obtained according to the method proposed by the authors within the metrological relative error of $\pm 10 \%$, which can serve as a good reason for the introduction of the express method in everyday laboratory practice. 


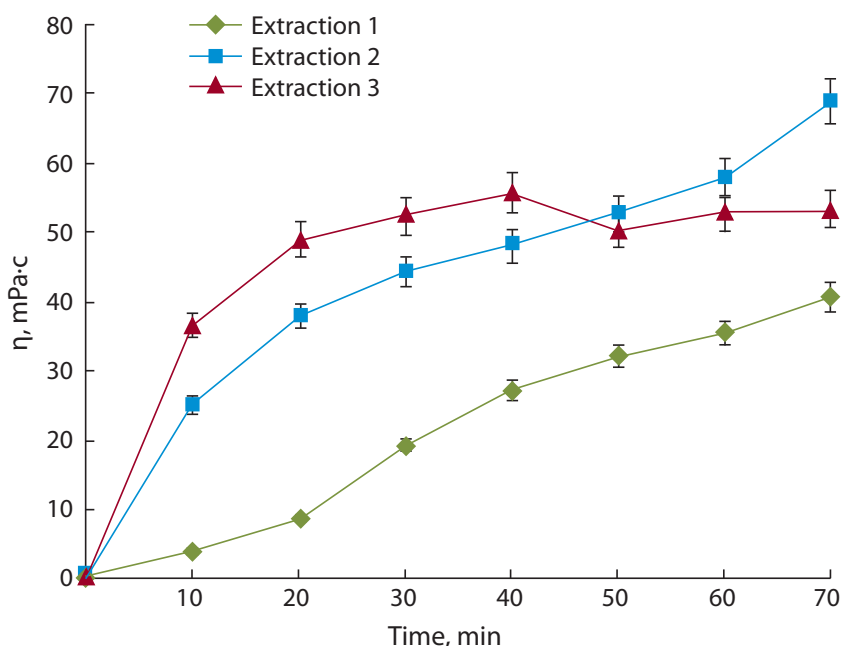

Fig. 1. Kinetics of viscosity changes in three successive extracts from boiled guar seeds.

\section{Assessment of gum content and viscosity in the seeds of guar accessions grown under different environmental conditions}

The developed method for the rapid assessment of the content and viscosity of gum extracts allowed us to analyze the seeds of 13 guar accessions grown in 4 geographical points of ecological testing. The average percentage of gum in the seeds of 13 test samples varied from $35.4 \%$ (Kuban) to $40.7 \%$ (Volgograd). According to the results of the Student's $t$-test ( $t$-test, dependent samples), guar seeds grown under the conditions of Volgograd region contained a significantly higher percentage of gum compared to seeds grown in Astrakhan $(p<0.008)$, Dagestan $(p<0.011)$ and Kuban $(p<0.009)$ (Fig. 2, $a)$. The average specific viscosity of gum extracts was maximal for seeds propagated in the Astrakhan branch (10305), and significantly exceeded this indicator compared to seeds obtained in Volgograd $(p<0.0005)$, Dagestan $(p<0.003)$ and Kuban $(p<0.001)$ (see Fig. $2, b)$.

When comparing seeds of the same accession grown under different ecological conditions in terms of gum content and specific viscosity, the correlation turned out to be not significant (Fig. 3, $a, b$ ). Thus, environmental conditions during cultivation of guar significantly affect the level of accumulation and properties of gum as a reserve polysaccharide of guar seeds.

\section{Preparation of dry powder gum samples from seeds of different guar varieties in laboratory conditions}

In addition to the laboratory assessment of the content and specific viscosity of gum extracts by the express method developed, we also attempted to produce in laboratory conditions samples of powder gum from the seeds of 3 out of 13 tested guar accessions. The accessions selected were the first guar varieties bred in Russian Federation: Kubanskii, Kubanskii Jubileinyi and Sinus. The seeds propagated in the Astrakhan branch of VIR were used.

At the first stage of preparation of powdered gum, after soaking, the guar seeds were fractionated manually, isolating the endosperm (split) from the hull and germ (cotyledons with
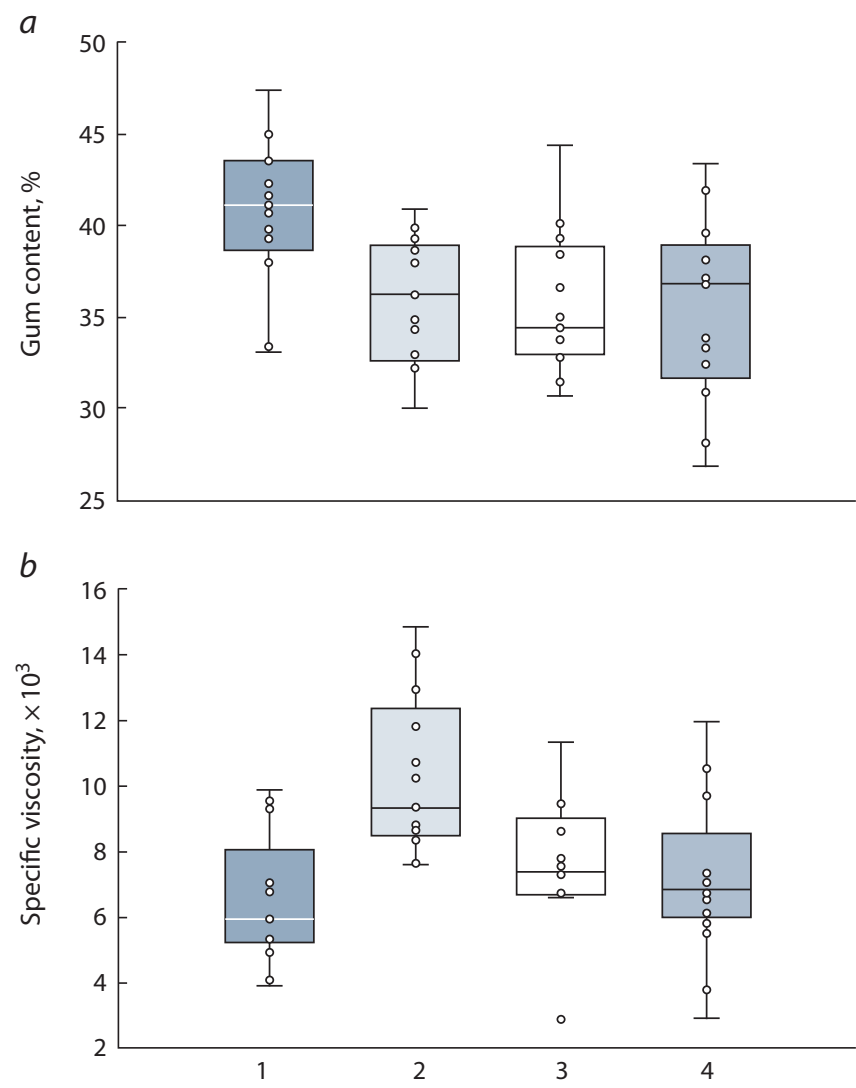

Fig. 2. Comparison of average percentages of gum (a) and specific viscosity of gum extracts $(b)$ in seeds of 13 guar accessions grown the Volgograd (1), Astrakhan (2), Dagestan (3) and Kuban (4) branches of VIR.

the embryo). The separated endosperms were then dried at $105^{\circ} \mathrm{C}$ for $20 \mathrm{~min}$ as suggested by Sabahelkheir et al. (2012) (Fig. 4, a). Further isolation of the gum from the endosperm was carried out after $100 \mathrm{~g}$ of split were boiled (30 min, $\left.121{ }^{\circ} \mathrm{C}\right)$, and three rounds of extraction at room temperature (1 hour each) were conducted. Insoluble residues were removed by centrifugation. After each extraction, the gum fraction was precipitated with acetone, dried at $105^{\circ} \mathrm{C}$ in air and ground. The resulting dry powdered gum samples obtained after three successive extraction steps are shown in Fig. 4, $b$. The obtained dry powder guar gum samples (accessions No. 5 , 7 and 13, see Table 1) were then transferred to the laboratory of NIKA PetroTech company for the further analysis.

\section{Assessing of the powder guar gum samples} as a gelling agent for hydraulic fracturing fluid

In the oil industry one of the most actual methods for increasing the efficiency of producing wells is hydraulic fracturing, which results in increased oil recovery from the oil reservoir (Silin et al., 2013). Hydraulic fracturing is a process in which fluid pressure acts directly on the oil-bearing rock until it collapses and a crack occurs.

To create hydraulic fractures in oil-bearing rock and to pump proppant there, an aqueous polysaccharide gel is commonly used. For more than 50 years, guar-based fluids and guar derivatives have been used as thickeners to create linear gels. Since the late 1960s and in present the so-called 
$a$

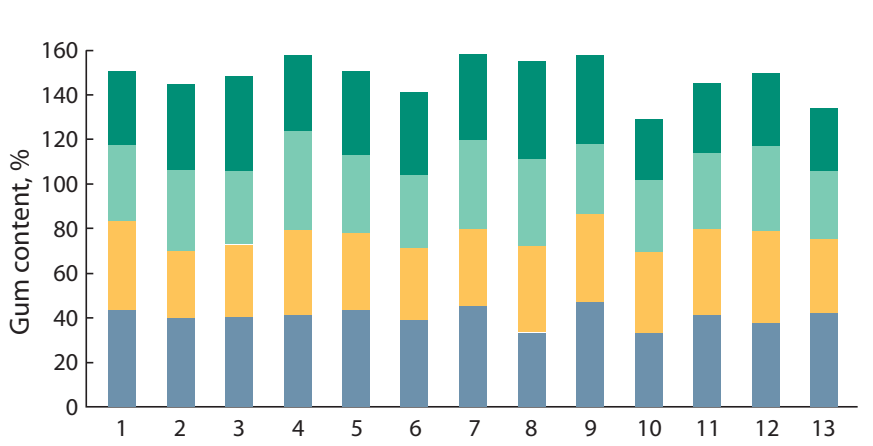

b Branches of VIR:

- Kuban

- Dagestan

Astrakhan

- Volgograd

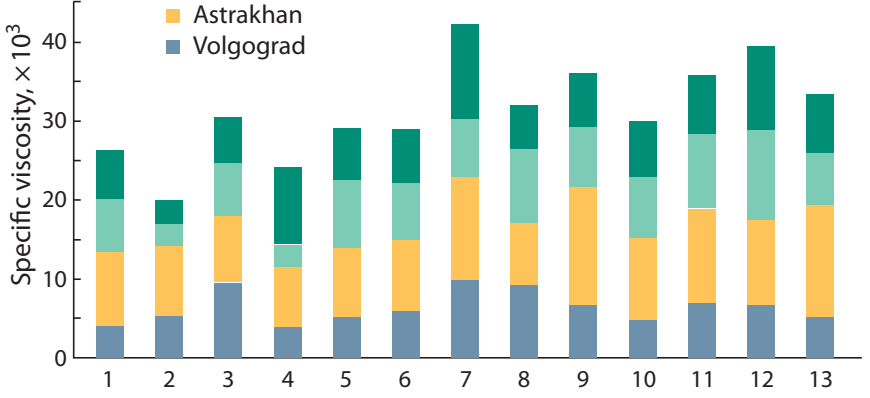

Fig. 3. Comparison of the quantity and quality of gum in the seeds of 13 guar accessions grown at different VIR experimental stations in 2018: $a$, gum content (\%) in the seeds of the accessions; $b$, specific viscosity of gum extracts from seeds of the accessions.

The numbers on the $\mathrm{X}$-axis correspond to the numbers of the accessions in Table 1.
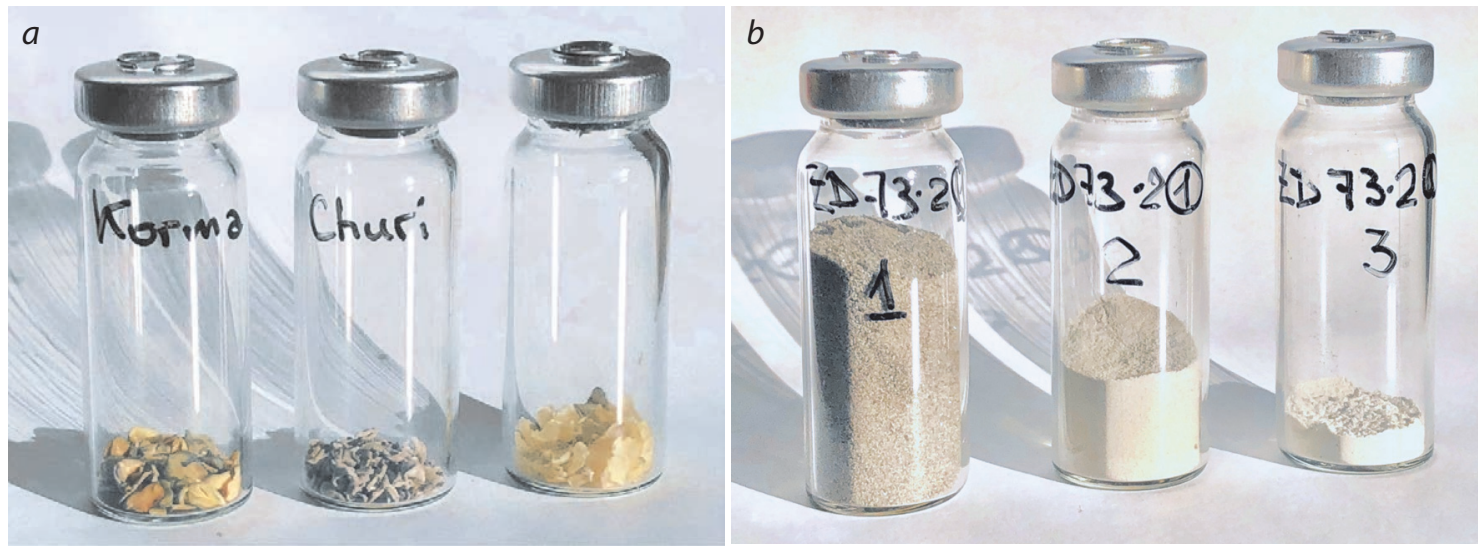

Fig. 4. Preparation of dry powder gum samples from guar seeds in laboratory conditions. $a$, fractions of seeds: embryo and cotyledons (korma), seed coat (churi) and endosperm (split) containing gum; $b$, dry gum powder obtained from endosperm: from left to right - after three successive extraction (purification) steps.

"cross-linked" hydraulic fracturing fluids are used - solutions of polysaccharides that are complexed with multivalent ions of boron and other metals (cross-linkers). When a linear gel interacts with a cross-linker, complex bonds form between polymer chains. This interaction creates a cross-linked system, turning a low-viscosity fluid (linear gel) into a highly viscous structured fluid (cross-linked gel) that can hold and transport proppants into the oil-bearing formation to increase conductivity.

In NIKA PetroTech company three samples of powder gum obtained in the laboratory conditions were tested to their ability to provide a stable gel cross-linked with boroncontaining agents with high sand-bearing characteristics. An estimated qualitative characteristic of a cross-linked hydraulic fracturing fluid is the ability to form a "tongue" (Fig. 5). The presence of the "tongue" indicates the sufficient viscosity of the obtained cross-linked gel. The viscosity of a linear gel is considered to be working at $40-45 \mathrm{mPa} \cdot \mathrm{s}$; while the viscosity of the cross-linked system should be in the range of more than $300-400 \mathrm{mPa} \cdot \mathrm{s}$, depending on the particular requirements.

As follows from the Table 2, the final viscosity of the gum powder solution (linear gel) obtained from the seeds of varieties Kubanskii and Kubanskii Jubileinyi reaches the required threshold level after $30 \mathrm{~min}$ (41.1 and $36.2 \mathrm{cP}$, respectively). This indicates the potential possibility of obtaining powder gum with desired properties from guar seeds produced in the Russian Federation. By the speed of viscosity increase, which is determined by the ratio of the viscosity index after 3 min of hydration to the maximum value of viscosity, the Sinus guar variety was distinguished.

Figure 6 shows that the obtained cross-linked gel meets the minimum quality requirements for fracturing fluid. A decrease in viscosity during the first $35 \mathrm{~min}$ is a typical thermal attenuation of the system and is acceptable; from 35 to $60 \mathrm{~min}$, the average viscosity stabilizes and reach a value of $350 \mathrm{mPa} \cdot \mathrm{s}$. The standard concentration of dry gel in the hydraulic fluid is $3.6 \mathrm{~kg} / \mathrm{m}^{3}$. A higher concentration of the obtained product $\left(4.8 \mathrm{~kg} / \mathrm{m}^{3}\right)$ indicates that it is necessary to refine the cleaning process of the dry powder gum, as well as to conduct additional investigations of the molecular weight distribution of the resulting polymer.

\section{Discussion}

Galactomannan (guar gum), a water-soluble reserve polysaccharide of guar seeds, is used as a gelling agent in liquids, including in the oil and gas industry for hydraulic fracturing. In 


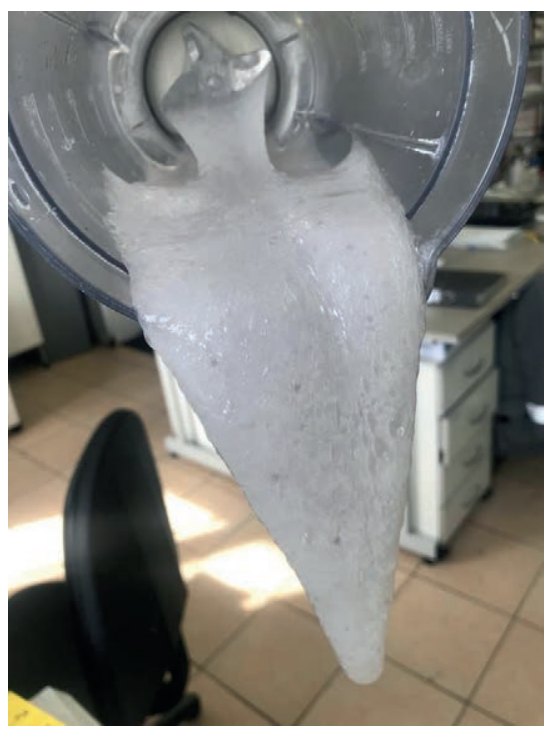

Fig. 5. Appearance of a cross-linked gel obtained from a laboratory sample of powder gum (cv. Kubanskii).

our study it was found that the different guar varieties possess distinct values of the total content and specific viscosity of gum extracts from seeds, and these indicators can vary significantly depending on the guar variety and the conditions of its cultivation.

For a comparative study of properties of gum contained in the seeds of various guar genotypes for the first time we proposed a rapid laboratory method for obtaining gum extracts for the gum quantity and viscosity evaluation. The developed method allows fast screening of the breeding material for the selection of guar varieties, promising from the point of view of using gum manufactured from their seeds in the oil and gas industry. The results of applying of the new method for the laboratory assessment of the content and viscosity of gum in the seeds of 13 guar samples

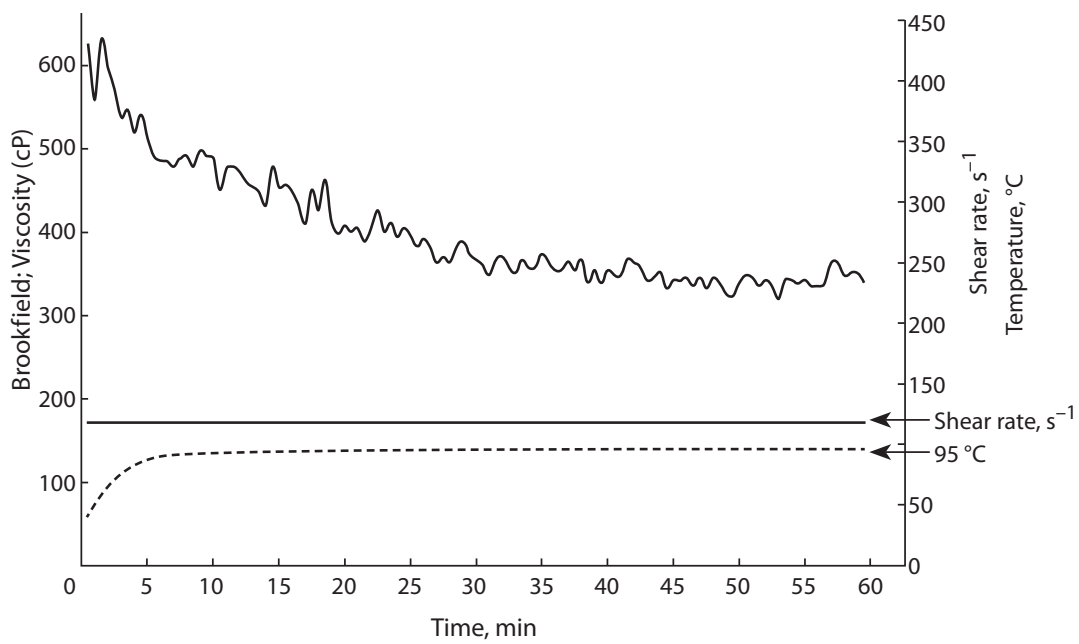

Fig. 6. Graph of the temperature stability of a cross-linked guar-borate gel obtained at a temperature of $95^{\circ} \mathrm{C}$ from a powdered gum sample prepared from seeds of guar accession No. 5, propagated at the Astrakhan branch of VIR (upper broken line).

The left ordinate axis represents the viscosity index in CP (Brookfield; Viscosity). Two constant values are plotted on the right axis: a solid straight horizontal line reflects the constant speed of rotation of the beaker with the sample (Shear rate, 117.6 rotations per sec); the dashed line represents the temperature of the system $\left(95^{\circ} \mathrm{C}\right)$.

showed that the yield and properties of the gum of the same variety vary greatly depending on the growing conditions.

Until now, attempts to grow guar as an industrial crop have been carried out in the Krasnodar region (Lebed et al., 2017), and in the Crimea, where guar is usually grown without irrigation (on a dry land). Although some success in obtaining yield in these regions was achieved, the risks of yield loss in the absence of rainfall during critical periods of plant development were also revealed. Thus, the idea of the possibility of guar production in the Lower Volga region using irrigation has now received support according to our results obtained from environmental tests of guar genotypes in different regions of the country.

So, the 2018 experiment on growing the same set of 13 guar accessions at four VIR experimental stations (Volgograd, Astrakhan, Dagestan and Kuban branches) showed that the maximum specific viscosity of gum was detected for seeds obtained in the Astrakhan branch, where irrigation is usually applied. Subsequent analysis of powder gum samples obtained in laboratory conditions from the seeds of three guar varieties grown at the Astrakhan branch also showed their potential suitability for industrial use. On the other hand, the maximal gum content among the all guar accessions tested was recorded for the seeds propagated under the conditions of the Volgograd branch of VIR with drip irrigation. The results are preliminary, as they are based on the results of environmental tests of just one year. However, they indicate that, given the appropriately developed technology for propagation of this crop under unusual growing conditions, the idea of cultivating guar with irrigation

Table 2. Physical and chemical parameters of the guar gum powder obtained from the seeds of three guar varieties reproduced in the Astrakhan branch of VIR

\begin{tabular}{|c|c|c|c|c|c|c|}
\hline Parameter & Kubanskii & $\begin{array}{l}\text { Temperature, } \\
{ }^{\circ} \mathrm{C}\end{array}$ & $\begin{array}{l}\text { Kubanskii } \\
\text { Jubileinyi }\end{array}$ & $\begin{array}{l}\text { Temperature, } \\
{ }^{\circ} \mathrm{C}\end{array}$ & Sinus & $\begin{array}{l}\text { Temperature, } \\
{ }^{\circ} \mathrm{C}\end{array}$ \\
\hline \multicolumn{7}{|c|}{ Viscosity of gum powder solution, $\mathrm{mPa} \cdot \mathrm{s}$} \\
\hline initial (3 min) & 4.7 & 20.7 & 2.3 & 21.9 & 10.2 & 21.2 \\
\hline final (30 min) & 41.1 & 21.4 & 36.2 & 22.4 & 29.2 & 19.0 \\
\hline $\mathrm{pH}$ & 7.16 & 20.7 & 6.59 & 22.1 & 6.65 & 19.0 \\
\hline
\end{tabular}


in the Astrakhan and Volgograd regions can be promising and get support from the agribusiness.

\section{Conclusion}

Assessing of the powder guar gum samples prepared from seeds of guar varieties developed in Russian Federation allow us to conclude that the product is suitable for use as a gelling agent for hydraulic fracturing fluid used intensify oil and gas production. This experience is new to the Russian Federation.

\section{References}

Abidi N., Liyanage S., Auld D., Imel R.K., Norman L., Grover K., Angadi S., Singla S., Trostle C. Challenges and opportunities for increasing guar production in the United States to support unconventional oil and gas production. In: Uddameri V. et al. (Eds.). Hydraulic Fracturing Impacts and Technologies. CRC Press, Boca Raton, 2015;207-226. DOI 10.1201/b18581.

Cerqueira M.A., Pinheiro A.C., Souza B.W., Lima A.M.P., Ribeiro C., Miranda C., Teixeira J.A., Moreira R.A., Coimbra M.A., Goncalves M.P., Vicente A.A. Extraction, purification and characterization of galactomannans from non-traditional sources. Carbohydrate Polymers. 2009;75(3):408-414.

ECFA, Joint FAO/WHO Expert Committee on Food Additives Monographs 5, Compendium of Food Additive Specifications from 69th JEFCA Meeting, Rome, June 17-26, 2008. Available at: http:// www.fao.org/3/a-at870e.pdf

Eldirany A.A., Azhari A. Mohamed N., Khadir E.K., Gadeen K.A., Ibrahim M.A.E.M. Physicochemical and functional properties of four new genotypes (Cyamopsis tetragonoloba L.) of guar gum. Am. J. Food Sci. Health. 2015;1(2):43-50.

Ellis P.R., Qi Wang, Rayment P., Ren Y., Ross-Murphy S.B. Guar gum: agricultural and botanical aspects, physicochemical and nutritional properties and its use in the development of functional foods. In: Cho S.S. (Ed.). Handbook of Dietary Fiber. CRC Press, 2001; 613-659.

Hanson T. The Triumph of Seeds: How grains, nuts, kernels, pulses, and pips conquered the plant kingdom and shaped human history. New York: Basic Books, 2015.

Lebed D.V., Kostenkova E.V., Voloshin M.I. Agronomic rationale for the placement of Cyamopsis tetragonoloba $\mathrm{L}$. in the south of the European part of Russia. Tavricheskiy Vestnik Agrarnoy Nauki = Taurida Herald of the Agrarian Sciences. 2017;1(9):53-64. (in Russian)

McArdle R., Hamill R., Kerry J.P. Utilisation of hydrocolloids in processed meat systems. In: Kerry J.P., Kerry J.F. (Eds.). Processed Meats: Improving Safety, Nutrition and Quality. 1st edn. Cambridge, UK: Woodhead Publishing Ltd., 2011;243-269. DOI 10.1016/B9781-84569-466-1.50028-3.

Sabahelkheir M.K., Abdalla A.H., Nouri S.H. Quality assessment of guar gum (endosperm) of guar (Cyamopsis tetragonoloba). ISCA J. Biol. Sci. 2012;1(1):67-70.

Silin M.A., Magadova L.A., Chirina L.A. Investigation of the effect of boron ions and mineral salts present in tank water on the quality of hydrofracturing polysaccharide liquids. Vesti Gazovoy Nauki $=$ Gas Science News. 2013;1(12):73-78. (in Russian)

Thombare N., Jha U., Mishra S., Siddiqui M.Z. Guar gum as a promising starting material for diverse applications. Int. J. Biol. Macromol. 2016;88:361-372. DOI 10.1016/j.ijbiomac.2016.04.001.

ORCID ID

E.K. Potokina orcid.org/0000-0002-2578-6279

Acknowledgements. The study was financially supported by the Ministry of Equation and Science of the Russian Federation, project RFMEFI60417X0168, Agreement No. 14.604.21.0168.

Conflict of interest. The authors declare no conflict of interest.

Received June 4, 2019. Revised September 4, 2019. Accepted September 5, 2019. 